\title{
Architectural heritage as the basis for the formation of the modern image of the city
}

\author{
Tatiana Goranskaya ${ }^{1}$
}

\section{ABSTRACT:}

The article analyzes the artistic interpretations of objects of architectural heritage from paintings and graphics, as the basis for the formation of the modern image of the city.

\section{KEYWORDS:}

architectural heritage; city image; fine arts

\section{Introduction}

As a result of the modern processes of globalization and urbanization, many objects of architectural heritage, historical places in the city, acquire new functions, change their appearance and their inherent meaning, as well as their significance in the city. The city loses its "soul" (N. Antsiferov) when the continuity of historical and cultural memory is interrupted.

The problem of preserving the historically formed uniqueness of an urban space comes down to the everyday practices of local communities, when "the special is not just preserved, but... acquires" new forms in the context of intercultural and interethnic dialogue [1]. The interaction between cultural traditions of different peoples in the space of a modern city levels the boundaries between "our" and "alien" worlds, allowing it to be interpreted as a "crossroads" as a means of communication between generations and social communities. Works of architecture from different historical epochs and cultures are important for the sustainable development of urban space, comprehension of the present and a source of inspiration for new architectural forms in the continuing transformation of the urban landscape.

Changes in the objective material, as well as cultural and social realities go hand in hand with their "documentary" reflection of the visual arts and the creation of the image of the city by artists. Cultural heritage is becoming an important element in the formation of the modern image of the city.

The purpose of this article is to analyze the artistic interpretations of the architectural heritage, featured in paintings and graphics, as the basis of the modern image of the city.

\section{Discussion}

The modern image of the city in the visual arts can be interpreted as a search for a compromise between the desire to contain the rapidity of change, preserving fragments of the past in the present, and reflecting the new interconnections of historical architectural objects and urban spaces with the life of modern society.

${ }^{1}$ State Scientific Institution "Center for Research of Belarusian Culture, Language and Literature of the National Academy of Sciences of Belarus", st. Surganov, 1/2, 220072, Minsk, Belarus, e-mail: tatakot@inbox.ru, orcid id: 0000-0002-6946-0094 
Formation of the image of a city is the process of highlighting individual elements of reality (architectural objects, everyday objects, etc.), giving them a semantic content that is generally significant and also significant for local cultures (in the context of urbanization and globalization), thereby creating a new model of interconnections between the world and the person. In parallel with the image of the city, a new individual and collective identity (a city, within a city) is being constructed, as a set of semantic meanings of places, based on the interpretation of works of architecture.

In contemporary visual arts, the following approaches to the depiction of architectural heritage by artists can be distinguished, as the basis of the image of the city:

1. Loss of certainty of the appearance of urban buildings and structures, "disappearance" of certain places and fragments of urban reality. The decisive factor for creating the image of the city by the French artist Van Tame is, the continuous daily bustle of life in the metropolitan areas of New York and London, which can turn into a single bright round dance of colorful spots without definite shapes and clear outlines. In this context, the blurred silhouette of the S. Guggenheim Museum in New York acts as an element of the stability of the urban space, making it possible to recognize it (Fig. 1). Inheriting the tradition of impressionism, the artist conveys the "spirit of the place", accentuating the instant impression through color combinations and dynamic brushstrokes. He notes: "I like to capture the trace of movement ...".

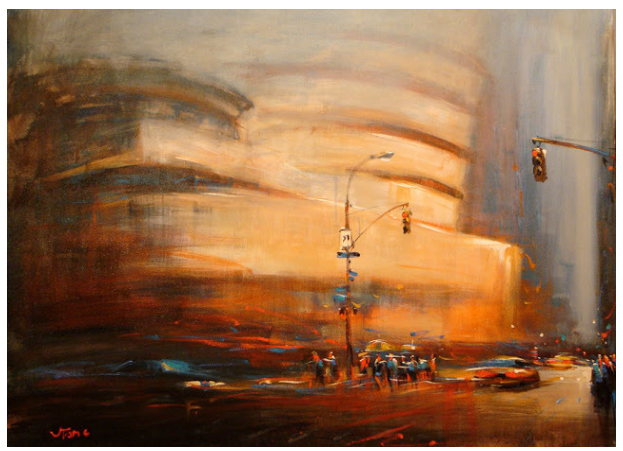

Fig. 1. Van Tame

2. Connecting fragments of the old and the new in the urban space, as a transformation of the "spirit of the place" and the identity of the city (with the city). The creation of the image is based on the dialogue of many cultures and heritage.

2.1. A "mosaic" of modern architectural forms and new social practices that are woven into the fabric of the old city, changing the functions and semantic meanings of historical places where the past exists simultaneously with the present, this is the basis for creating the image of the city by the Russian artist I. Slavinsky. The space of Boulevard Haussmann opposite the Grand Opera in Paris, next to the Galeries Lafayette combines two sides of reality: the material visible (everyday) and the mysterious, hidden from prying eyes behind blurred silhouettes (Fig. 2). The image of the artist's city is a combination of the "obvious" and "incredible", "in which the material world, objective reality retained their concrete real appearance, but at the same time acquired some otherworldly, transcendental meaning that lies outside the boundaries of the everyday, everyday, rationally comprehensible system of measures" (magic realism) [2, p. 38].

2.2. The composition of architectural elements and forms of different historical eras, cultures and styles in their new combinations, developing according to the laws of the game, is one of the ways for artists to search for the identity ${ }^{2}$ of a global city, a city of global culture ....

2 The Norwegian architectural theorist H. Scott believed that identity is a "trace" that civilization leaves behind as it moves through history and that refers to various cultural layers and images. 


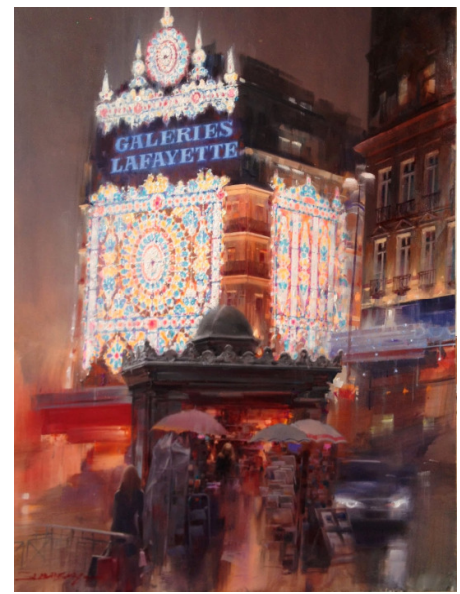

Fig. 2. I. Slavinsky

The image of a city, as a model of the universe, is not reduced to the idea of any particular city and is formed through a system of archetypes that reflect both the main features of traditional cities and the idea of timelessness of urban civilization. Archetypes (house, labyrinth, world tree) and symbols of ancient cities (Babylon), which are addressed by modern artists, on the one hand, are stable, recognizable and universal, and, on the other, they lose direct connection with their historical prototypes (Figs. 3, 4).

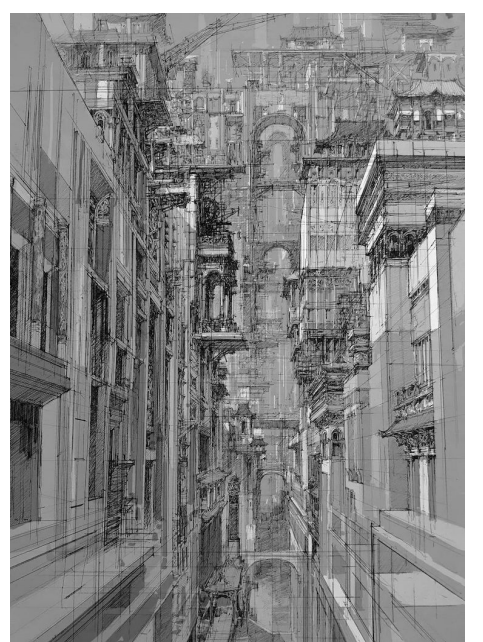

Fig. 3. Jae Cheol Park (Paperblue)

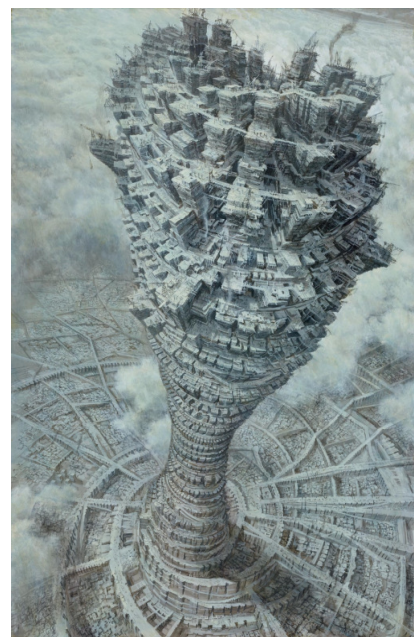

Fig. 4. L. Gapaillard

Fragments of architectural objects from different eras and peoples become the basis, connecting the past and the present "in various existential topographies of cultural forms" [3]. In the works of Jae Cheol Park (Paperblue) and L. Gapaillard this trend is expressed in the depiction of non-existent cities of places, where "modern technologies" are mixed with "other times, ... spaces, ... paradigms", dating back to the depths of the centuries (Figs. 3, 4) [4]. In the artists' drawings, buildings, doorways and arches, fragments of the classical order and roofs of traditional Korean buildings, cranes and scaffolding are connected to each other and form a holistic, detailed urban space "without beginning and end." Attention to detail allows you to perceive the fictional world as a true reality. 
3. Opposition - the life of a small city within a large one, as the preservation of the "spirit of the place".

M. Castells emphasized the importance of local identities in the conditions of the modern information society, "when the world becomes too big to be controlled, and social subjects seek to reduce it back to a meaningful size ... when people seek ... to remember their historical memory" [5, p. 33].

In the interpretation of artists, the unique forms of historically formed urban spaces, the appearance of buildings and traditional everyday social practices reflect the connection of human existence with a specific place, where life proceeds in a familiar and predictable manner. Individual volumetric-spatial characteristics (features) of a place are connected with the "space of relations" (S. McQuire), preserving the "spirit of the place" and giving it meaning. 3.1. The Old City is a legacy of the past, a symbol of authenticity and continuity of the history and culture of the city, that exists in the present.

Temples, town halls, medieval streets, courtyards, wells, inconspicuous back streets, black staircases and roofs of dilapidated houses are interpreted by artists as materialized memory. Emphasizing the materiality of the environment (surface textures, masonry wall shapes, etc.). M. Orlovsky creates a feeling of "involvement" in the life of the old city (Fig. 5).

3.2. Fantasies about a city of the past are a combination of many existing and/or non-existent architectural objects, their fragments, household items from different eras, etc., referring to the history of individual cities and places. In the image of urban space N. Rozumenko uses the tradition of "collective" veduta, where recognizable works of architecture, fragments of historical buildings, etc., are combined in an arbitrary combination, creating an illusory space, or "fantasy" fictional views (Fig. 6).

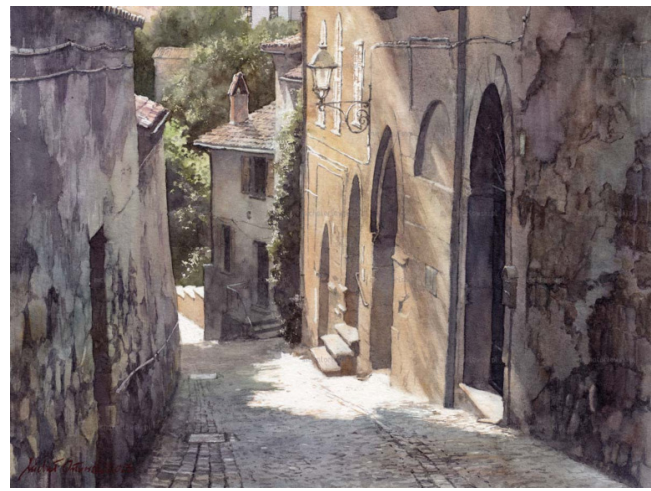

Fig. 5. M. Orlovsky

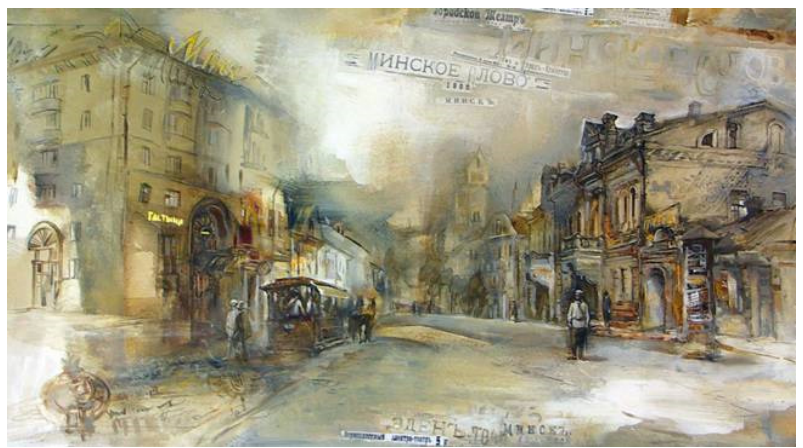

Fig. 6. N. Rozumenko 


\section{Conclusions}

The modern image of the city, as a combination of the "spirit of the place" and the "spirit of the times", is formed in the context of the dualism of cultural universalization and the desire of local communities to preserve the uniqueness of the historically formed urban landscape, traditional local practices of everyday culture, etc.

The following approaches to the depiction of architectural heritage by artists, as the basis of the image of the city, are highlighted: the loss of individuality and the "disappearance" of fragments of urban reality; intercultural and interethnic dialogue "old and new" ("mosaic", "composition"); "the life of a small town inside a big one" ("old town", "fantasies about the past").

To emphasize the connection with the past, iconography uses historical architectural forms and archetypes (labyrinth, stairs, Tower of Babel, etc.).

Modern images of the city are characterized by a view "from the inside" and "from below" (tradition of flanering), realistic details and their combination according to mythical, folklore laws of space organization (tradition of "magic realism").

The work was carried out with funding from the Belarusian Republican Foundation for Basic Research (contract G20-062 of 05/04/2020).

\section{References}

[1] Ionin L., New magic era [Electronic resource], Access mode: http://www.ruthenia.ru/logos/number/ 47/13.pdf, Access date: 10.01.2021.

[2] Gugnin A.A., Magical realism in the context of literature and art of the twentieth century (Phenomenon and some ways of understanding it), Russian Academy of Sciences. Institute of Slavic Studies. Scientific Center for Slavic-Germanic Studies, Moscow 1998.

[3] Boym S., The future of nostalgia [Electronic resource] Series "Library of the journal" Neprikosnovy zapas", Access mode: https://www.litres.ru/svetlana-boym-19857950/buduschee-nostalgii/chitat-onlayn, Access date: 05.08.

[4] Davis E., Technognosis: myth, magic and mysticism in the information age, Ultra. Culture, Yekaterinburg 2008.

[5] Fedotova N.G., Formation of urban identity: factorial and institutional aspects, Journal of Sociology and Social Anthropology 2017, 20(3), 32-49.

\section{Dziedzictwo architektoniczne jako podstawa kształtowania współcze- snego obrazu miasta}

\section{STRESZCZENIE:}

W artykule przeanalizowano artystyczne interpretacje obiektów dziedzictwa architektonicznego (przedstawione w malarstwie i grafice), które są podstawą kształtowania nowoczesnego wizerunku miasta. Pokazano, że współczesny wizerunek miasta jest połączeniem „ducha miejsca” i „ducha czasu” i kształtuje się w kontekście dualizmu kulturowej uniwersalizacji i dążenia społeczności lokalnych do zachowania historycznej tożsamości krajobrazu miejskego. Opisano następujące metody odtwarzania dziedzictwa architektonicznego jako podstawy obrazu miasta przez artystów: utrata indywidualności i „zanikanie” fragmentów miejskiej rzeczywistości; międzykulturowy i międzyetniczny dialog „starego i nowego” („mozaika”, „kompozycja”) oraz „życie małego miasta w dużym” („stare miasto”, „fantazje o przeszłości”).

\section{SŁOWA KLUCZOWE:}

dziedzictwo architektoniczne; obraz miasta; sztuki piękne 